Связъ изменений относительной длины теломер в течение пятнадцати лет с маркерами возрастных изменений сердечнососудистой системы у лиц среднего возраста по результатам исследования питания и рака в Мальмё (Швеция)

\author{
Нильсон П.М., Дальман Д., Меландер О. \\ Университет Лунда, Университетская больница Сконе (Мальмё, Швеция)
}

\title{
Change in relative telomere length over fifteen years is associated with markers of cardiovascular ageing in middle-aged subjects - the Mallmo̊ Diet and Cancer Study, Sweden
}

Nilsson P.M., Dahlman D., Melander O.

Lund University, Skåne University Hospital (Malmö, Sweden)

\section{АННОТАЦИЯ}

Цель. Проанализировать связь между длительными изменениями относительной длины теломер (ОДТ) и отдельными маркерами возрастных изменений сердечно-сосудистой системы, такими как инфаркт миокарда (ИМ) в анамнезе, пульсовое давление или прием антигипертензивных препаратов (АГП) за 15-летний период наблюдения.

Материалы и методы. В исследовании приняли участие 332 пациента среднего возраста с ИМ в анамнезе. ОДТ крови при первичном обследовании и спустя 15 лет определялась методом количественной ПцР. Для сравнения логарифмического распределения ОДТ на начальном и финальном этапах исследования использовался z-тест. Разница ( $\Delta \mathrm{z}$-оценка) рассчитывалась для каждого больного как маркер относительного изменения длины теломер за 15 лет. Множественный регрессионный анализ проводился c $\Delta \mathrm{z}-$-ценкой как зависимой переменной; независимыми переменными являлись возраст, пол, исходный уровень ОДТ и клинические маркеры возрастных изменений сердечно-сосудистой системы.

Результаты. Установлено, что исходно $\Delta \mathrm{z}$-оценка ОДТ независимо связана как со случаями (дебютными/ повторными) ИМ ( $p<$ o.039), так и с приемом АГП ( $p<0.015)$ на момент начала исследования. У лиц с ИМ в анамнезе или принимающих АГП наблюдалось большее снижение z-оценки для ОДТ за период исследования, что свидетельствует о более высокой степени укорочения теломер.

Заключение. Изменения ОДТ (их истощение) крови являются потенциальным маркером возрастных изменений сердечно-сосудистой системы, что подтверждается наличием значимой и независимой корреляционной связи между $\Delta \mathrm{z}$-оценкой и дебютным/повторным ИМ, а также исходным приемом АГП, являющимися признаками многолетней гипертонии, требующей лечения.

Ключевъе слова: антигипертензивные препараты, возрастные изменения сердечно-сосудистой системы, когорта, эпидемиология, инфаркт миокарда, теломеры.

\section{ABSTRACT}

Objective. To analyse the association between long-term changes in relative telomere length (RTL) and selected markers of cardiovascular ageing such as history of myocardial infarction (MI), pulse pressure or usage of antihypertensive (AHT) drugs during 15 years of follow-up.

Subjects and methods. 332 middle-aged subjects were recruited from a population-based, case-control study of patients with MI. RTL in blood at baseline and after 15 years of follow-up was investigated through quantitative PCR. Z-statistics was used to compare the log-distribution of RTL at baseline and at follow-up, respectively. The difference $(\Delta \mathrm{z}$-score) was calculated for each individual as a marker of relative change in telomere length over 15 years. Multiple regression analysis was used with $\Delta$ z-score as dependent variable, and age, sex, RTL at baseline, and clinical markers of cardiovascular ageing as independent variables.

Поступила 12.12.2018

Принята 15.12.2018

*Автор, ответственный за переписку

Нильссон П.М.: Университет Лунда, Jan Waldenstroms gata, 15, 5-й этаж, университетская больница Сконе, S-205 02, Мальмё, Швеция.

E-mail: Peter.Nilsson@med.lu.se
Received 12.12.2018

Accepted 15.12.2018

*Corresponding author

Nilsson Peter M.: Lund University, Jan Waldenstroms gata, 15, $5^{\text {th }}$ floor, Skåne University Hospital, S-205 02, Malmö, Sweden.

E-mail: Peter.Nilsson@med.lu.se 
Results. We found that $\Delta$ z-score of RTL was independently associated with both total (prevalent/incident) MI $(p<0.039)$ and usage of AHT drugs $(p<0.015)$ at baseline. Subjects with MI or on AHT drugs showed a greater reduction in the z-score for RTL during follow-up, implying a higher degree of telomere shortening.

Conclusion. Changes in blood relative telomere attrition (RTL) is a potential marker of cardiovascular ageing, as illustrated by significant and independent associations between $\Delta \mathrm{z}$-score and prevalent/incident MI, as well as with baseline usage of antihypertensive drugs - a marker of longstanding hypertension in need of treatment.

Keywords: antihypertensive drugs, cardiovascular ageing, cohort, epidemiology, myocardial infarction, telomere.

\section{ВВЕЛЕНИЕ}

Теломеры формируют конечный сегмент хромосомной спирали, играя важную роль в защите концов хромосом при репликации клеток [1]. Длина теломер в первую очередь регулируется генетическими факторами [2], существуют также и некоторые другие факторы, влияющие на длину теломер или активность регулирующего фермента - теломеразы [3]. До настоящего времени эпидемиологическое изучение связи теломер с хроническими заболеваниями основывалось главным образом на перекрестных исследованиях. Например, в ряде обсервационных исследований обнаружена связь коротких теломер с артериальной гипертензией и пульсовым давлением $[4,5]$, диабетом 2-го типа $[6,7]$, инсулинорезистентностью [8] и сердечно-сосудистыми заболеваниями, в частности, с риском ишемической болезни сердца (ИБС) [9-11], инсультом [12] и аневризмой брюшной аорты [13]. Это может быть обусловлено ожирением, хроническим воспалением или нездоровым образом жизни [14]. Вместе с тем полученные данные достаточно противоречивы; кроме того, предыдущие исследования редко строились на долгосрочных наблюдениях за связью изменений относительной длины теломер (ОДТ) и маркеров возрастных изменений сердечно-сосудистой системы.

Очевидно, что результаты перекрестных исследований ОДТ не дают полной картины происходящих с течением времени изменений теломер, связанных с риском сердечно-сосудистых заболеваний (СС3). По этой причине для сравнения скорости истощения теломер у пациентов с различным сердечно-сосудистым риском требуются долговременные исследования, которые до сих пор редко проводятся и потому являются крайне востребованными [15]. В некоторых исследованиях ранее было показано, что у 15-25 \% пациентов длина теломер со временем увеличивалась [16-18], что может быть связано с повышением активности теломеразы или влиянием изменения длины теломер в различных субпопуляциях мононуклеаров либо с методологическими погрешностями этих исследований. Следу-

\section{INTRODUCTION}

Telomeres form the end segment of the chromosomal helix and are of importance for end-protection during cell replication [1]. The telomere length is primarily regulated by genetic factors [2], but also some environmental factors have been shown to influence telomere length or activity of telomerase, the regulating enzyme [3]. So far, epidemiological research on telomere biology in relation to chronic disease conditions has mostly been based on cross-sectional studies. For example, in a number of observational studies it has been documented that short telomeres or the genetics regulating telomeres are associated with hypertension and pulse pressure $[4,5]$, type 2 diabetes $[6,7]$, insulin resistance [8], and cardiovascular disease manifestations, e.g. risk of coronary heart disease [9-11], stroke [12] and abdominal aortic aneurysm [13]. This could be due to the association with intermediate phenotypes such as obesity or chronic inflammation, or to the influence of a less healthy lifestyle [14]. However, some of the findings have also been contradictory, and previous studies did rarely include a long-term follow-up for determination of changes in relative telomere length (RTL) in relation to markers of cardiovascular ageing.

Cross-sectional data on measurements of telomere length are obviously not enough to evaluate the full importance of time-dependant changes according to telomere biology which are associated with cardiovascular risk. Therefore it takes longitudinal studies to compare the telomere attrition rate over time in defined subjects at varying cardiovascular risk, so far not often reported and therefore asked for [15]. In some studies it was previously shown that $15-25 \%$ of screened subjects might even increase their telomere length over time [16-18], maybe caused by an increased activity of telomerase or the influence of shifting telomere length in different sub-populations of mononuclear cells, or even represent an artefact due to methodological shortcomings. The influence of cardiovascular drugs on telomere biology and related changes should also 
ет также изучить влияние сердечно-сосудистых препаратов (например, антигипертензивных или гиполипидемических) на биологию теломер и происходящие с ними изменения [19].

\section{ЦЕЛЬ ИССЛЕДОВАНИЯ}

Анализ связи между длительным истощением теломер и некоторыми маркерами возрастных изменений сердечно-сосудистой системы, такими как инфаркт миокарда в анамнезе, пульсовое давление или применение антигипертензивных препаратов.

\section{МАТЕРИАЛЫ И МЕТОДЫ}

Для оценки истощения теломер за 15-летний период мы использовали данные по подгруппе пациентов, участвовавших в исследовании Malmö Diet Cancer - Cardiovascular Cohort (MDC-CC). В исследовании приняло участие 6103 чел. Первоначальное обследование проходило в 1991-1994 гг. в г. Мальмё (Швеция). Описание первоначального скринингового обследования было опубликовано в [20, 21], включая данные о посещаемости, характеристике лиц, не вошедших в выборку, а также методике исследования и самостоятельно заполняемом опроснике. В период с 2007 по 2009 г. в отделении клинических исследований университетской больницы в Мальмё было проведено повторное обследование лиц, участвовавших в первичном обследовании, которое позволило отобрать подгруппы пациентов для взятия проб крови, определения факторов риска и оценки истории болезни.

Из участников MDC-CC была сформирована группа из 714 чел., в которую вошли 88 больных с ИМ, произошедшим до первичного обследования; 198 чел., у которых ИМ развился после первичного обследования (до 31 декабря 2006 г.), и 458 чел. без ИМ (контрольная группа) за 15-летний период. Ниже описывается, как подтверждался диагноз ИМ.

Образцы крови испытуемых также использовались для перекрестного исследования связей между длиной теломер (на основе количественной ПЦР) после экстракции ДНК и различных факторов риска СС3 [22]. Однако для первой публикации использовались только данные по контрольной группе пациентов, не перенесших ИМ. Кроме того, в ходе совместного генетического исследования использовались образцы 226 пациентов с ИМ из числа участников MDC-СС (155 мужчин и 71 женщина) и 444 чел. без ИМ (306 мужчин и 138 женщин). Возраст составлял 48-68 лет (в среднем - 61 год) [23]. be further explored, e.g. antihypertensive or lipidlowering drugs [19].

\section{AIM OF THE RESEARCH}

To analyse the association between long-term telomere attrition and selected markers of cardiovascular ageing such as history of myocardial infarction, pulse pressure or usage of antihypertensive drugs.

\section{MATERIALS AND METHODS}

We used data from a subgroup of the Malmö Diet Cancer - Cardiovascular Cohort (MDC-CC) for the determination of telomere attrition during 15 years of follow-up. The MDC-CC was a population-based study ( $n=6$ 103) with a baseline investigation carried out in 1991 to 1994 in the city of Malmö, Sweden. Descriptions of the baseline screening have previously been published in full detail $[20,21]$, including data on attendance rate, characteristics of non-attendees, as well as methodologies and the self-administered questionnaire used. During the period 2007 to 2009 a re-screening examination of former MDC-CC subjects has taken place at the Clinical Research Unit at the University Hospital in Malmö, providing the opportunity to select sub-groups of subjects for blood sampling, determination of risk factors and evaluation of medical history during the follow-up.

Within the MDC-CC we established a case-control cohort $(n=714)$ with cases of myocardial infarction (MI) prior to the baseline exam, "prevalent MI" ( $n=88$ ), cases of MI which occurred after the baseline exam until December $31^{\text {st }}$ 2006, "incident MI" ( $n=198$ ), representing a total of unique 256 individuals with prevalent and/or incident MI, and control subjects free from MI prior to the baseline exam and during follow-up until December $31^{\text {st }} 2006$ $(n=458)$. The retrieval of MI case status is described below.

Blood samples from these subjects were also used for a collaborative study in order to investigate cross-sectional associations between telomere length (based on quantitative PCR) after DNA extraction and various cardiovascular risk factors [22]. However, only data from the non-MI controls were used for the first publication. In addition, the study material for a collaborative genetic study based on MDC-CC subjects consisted of 226 cases of myocardial infarction (155 men and 71 women) and 444 controls (306 men and 138 women). The age span of both the controls and MI patients was 48-68 years (mean 61) [23]. 
У 256 чел., перенесших ИМ до 2007 г., и 458 чел. без ИМ из контрольной группы были отобраны 332 чел. для повторного обследования (83 с ИМ и 249 без ИМ). У них длина теломер была измерена вторично (после первичного обследования лиц с СС3 из числа участников MDC-CC прошло в среднем 15.7 года (SD: o.8)). Затем скорость истощения теломер была проанализирована относительно трех маркеров возрастных изменений сердечно-сосудистой системы: 1) ИМ в анамнезе; 2) сведения пациентов об использовании АГП на момент начала обследования; 3) пульсовое давление (мм рт. ст.) на момент начала обследования как показатель жесткости артериальной стенки.

Исследование было одобрено региональным комитетом по этике в Лунде (LU 51-90, с дополнительным одобрением повторного исследования в рамках MDC-CC, начиная с 2007 г.)

\section{Регистрация случаев инфаркта миокарда}

Процедура установления ИМ уже была подробно описана ранее [23]. ИМ определялся как летальный или нелетальный, или смерть, вызванная ИБС. Случаи ИМ подтверждались с помощью выявления 10-значного персонального идентификационного номера каждого шведского гражданина в двух реестрах: шведском реестре выписанных больных (ШРВБ) и шведском реестре причин смерти (ШРПС). ИМ определялся на основе Международной классификации болезней 9-го и 10-го пересмотров (МКБ-9 и МКБ-10 - коды 410 и I21) в ШРВБ или ШРПС соответственно или смерти вследствие ИБС - коды 412 и 414 (МКБ-9) или I22-I23 и I25 (МКБ-10) в ШРПС. Классификация исходов с использованием этих реестров была предварительно подтверждена [24]. Исследование проходило до 31 декабря 2006 г.

Лабораторные методы: измерение длины теломер

Первичное обследование: образцы крови в исследовании MDC-СС были получены в 1991-1994 гг., фракции гранулоцитов хранились замороженными. Извлечение ДНК из биологических образцов мононуклеарных клеток проводили стандартными методами. Длина теломер измерялась методом ПЦР в реальном времени с использованием праймеров теломер и контрольных генов (бета-глобинов) в отдельных пластинах $[25,26]$. Относительная длина теломер определяется как отношение длины теломер к длине гена одной копии (HBG, человеческий бета-глобин). Все образцы были протестированы трижды. Для оценки длины теломер использовался $\Delta \Delta \mathrm{Ct}$ метод
Of the 256 individuals with MI before 2007 and the 458 control subjects free from MI until then, we have re-screened 332 subjects (83 MI-cases, and 249 non-MI controls) from the MDC-CC baseline investigation, after a mean of 15.7 (SD: 0.8) years of follow-up and re-measured telomere length. The telomere attrition rate has thereafter been analysed in relation to three selected markers of cardiovascular ageing: (a) MI case status; (b) self-report of usage of antihypertensive drugs at baseline; and (c) pulse pressure $(\mathrm{mm} \mathrm{Hg})$ at baseline, a marker of arterial stiffness.

The study was approved by the Regional Ethics Committee in Lund (LU 51-90, with additional approval for the re-screening of MDC-CC, starting in 2007).

\section{Registration of myocardial infarction}

The procedure for ascertaining MI events has been detailed previously [23]. In brief MI was defined as fatal or non-fatal MI or death due to ischemic heart disease. MIs were identified through linkage of the 10-digit personal identification number of each Swedish citizen with two registries: the Swedish Hospital Discharge Register (SHDR) and the Swedish Cause of Death Register (SCDR). MI was defined on the basis of International Classification of Diseases $9^{\text {th }}$ and $10^{\text {th }}$ Revisions (ICD9 and ICD10) codes 410 and I21 in the SHDR or SCDR, respectively, or death due to ischemic heart disease on the basis of codes 412 and 414 (ICD9) or I22I23 and I25 (ICD10) in the SCDR. Classification of outcomes using these registries has been previously validated [24]. Follow-up extended to December $31^{\text {st }} 2006$.

Laboratory methods: Measurement of telomere length

Baseline: Blood samples from the MDC-CC study were obtained between 1991 and 1994, and the granulocyte fractions were kept frozen. DNA extraction from mononuclear cell preparations was performed using standard procedures. Telomere length was investigated by real-time PCR using telomere-, and control-gene ( $\beta$-globin) primers in separate plates $[25,26]$. Relative telomere length (RTL) is defined as the relationship of telomere length to a single copy gene (HBG, human beta-globin) length. All samples were tested in triplicates. The $\Delta \Delta \mathrm{Ct}$ method with a reference DNA was used for telomere length evaluation and a standard curve was run on each plate to monitor PCR efficiency. The mean in- 
с эталонным образцом ДНК, и на каждой пластине была проведена стандартная кривая для мониторинга эффективности ПЦР. Средний коэффициент вариации между анализами, выполненный двумя исследователями в лаборатории, составил $3.96 \%$.

Повторное обследование: образцы крови в исследовании MDC-CC были получены в период с 2007 по 2009 г. и хранились замороженными до тех пор, пока ДНК не была извлечена из лейкоцитов периферической крови $(n=332)$ в 2009 г. ОДТ измерялась тем же методом, что и при первичном обследовании, однако использовались новый эталонный образец ДНК (US1) и различные амплификаторы, поскольку повторные измерения проводились в Мальмё, а первоначальные измерения - в Умео. Что касается исходных данных, то все образцы были протестированы трижды, и на каждой пластине была проведена стандартная кривая. Коэффициент вариации между анализами, рассчитанный для контрольной выборки по стандартной кривой на протяжении выполнения всех ПЦР-тестов, равнялся $19 \%$.

\section{Статистические методы}

Статистический анализ проводился с использованием SPSS 15.0 (статистический пакет для социальных наук, SPSS, Chicago, IL). Для получения нормального распределения применяли логарифмическое преобразование данных по длине теломер.

Поскольку при расчёте ОДТ мы использовали различные субпопуляции клеток для лабораторного контроля, у нас не было возможности точно сравнить значения ОДт, полученные в ходе первичного и повторного обследований. Вместо этого при сравнения логарифмического распределения ОДТ при первичном и повторном обследованиях использовалась z-статистика [27], соответственно, была рассчитана разница ( $\Delta \mathrm{z}$-оценка) для каждого участника в качестве маркера относительного изменения длины теломер в течение 15 лет. Скорость истощения теломер определялась как разница между стандартизированным значением (z-оценка) логарифмически преобразованной длины теломер при первичном обследовании (z-оценка ${ }_{\text {LNBL }}$ ) и стандартизированным значением логарифмически преобразованной длины теломер при повторном обследовании (z-оценка $\mathrm{LNFU}_{\text {f }}$ ), деленная на число лет между обследованиями.

При проведении множественного регрессионного анализа скорость истощения теломер использовалась в качестве зависимой переменной, а в качестве независимых переменных выступили мар- ter-assay coefficient of variation evaluated for this assay on human blood was $3.96 \%$ when run by two investigators in the laboratory.

Follow-up examination: Blood samples from the MDC-CC follow-up were obtained between 2007 and 2009, and were kept frozen until DNA was extracted from peripheral blood leukocytes ( $n=332)$ in 2009. RTL was measured by te same method that was used for the baseline measurements. However, a new reference DNA ("US1") and different PCR machines were used since the followup measurements took place in Malmö while the baseline measurements were carried out in Umeå. As for the baseline, all samples were tested in triplicates, and a standard curve was run on each plate. Inter-assay coefficient of variation was $19 \%$ calculated on a control sample in the standard curve throughout all the PCR-runs.

\section{Statistical methods}

Statistical analyses were performed using SPSS, version 15.0 (Statistical Package for the Social Sciences, SPSS, Chicago, IL). To achieve a normal distribution, log-transformed telomere length was used in all analyses.

Since we used different subpopulations of cells used for laboratory controls when calculating RTL, it was not possible to directly compare RTL values at baseline and at follow-up in individuals. Instead, z-statistics [27] was used to compare the logdistribution of RTL at baseline and at follow-up, respectively, and the difference was calculated ( $\Delta$ z-score) for each individual as a marker of relative change in telomere length over 15 years. The difference between the standardized value (z-score) of the LN-transformed telomere length at baseline (z-score $\mathrm{LNBL}_{\mathrm{L}}$ ) and the standardized value of the log-transformed telomere length at the re-exam (z-score ${ }_{\mathrm{LNFU}}$ ) divided by the follow-up time in years was defined as the telomere attrition rate [(z-score ${ }_{\mathrm{LNBL}} / \mathrm{z}^{\mathrm{z}}$ score $\left._{\mathrm{LNFU}}\right) /$ follow-up time in years].

Multiple regression analyses were performed by use of telomere attrition rate as the dependent variable and markers of cardiovascular ageing (total MI, use of AHT drugs, and baseline pulse pressure) as the independent variables, adjusted for chronological age, gender, and the baseline telomere length.

A $p$ value less than 0.05 was considered to be significant.

\section{RESULTS AND DISCUSSION}

A total of 332 subjects were investigated. Baseline characteristics showed $69 \%$ males, mean age 
керы возрастных изменений сердечно-сосудистой системы (случаи ИМ, применение АГП и исходное пульсовое давление) с поправкой на возраст, пол и исходную длину теломер.

Значение $p<0.05$ считалось значимым.

\section{РЕЗУЛЬТАТЫ И ОБУЖДЕНИЕ}

Всего в исследовании участвовало 332 чел. Первичное обследование: 69 \% мужчин, средний возраст 59.5 года $(\mathrm{SD}=5.1)$ и средняя ОДТ 0.65 (о.21). При повторном обследовании среднее значение ОДТ составило 1.37 (о.40), на которое повлияло использование другой методологии, основанной на иной популяции контрольных клеток. Клинические характеристики участников исследования исходно и при повторном скрининге приведены в табл. 1. Из всех 83 пациентов с ИМ у 33 ИМ произошел до начала исследования, у 56 в период проведения исследования; 67 пациентов принимали АГП к началу исследования. При первичном обследовании среднее пульсовое давление составляло $55.0 \pm 13.8$ мм рт. ст.

На рис. 1 показано распределение z-оценки при первичном и повторном обследованиях и разница между измерениями, отражающая укорочение теломер ( $\Delta \mathrm{z}$-оценка).

При проведении множественного регрессионного анализа было выявлено, что $\Delta \mathrm{z}$-оценка независимо коррелировала как с ИМ ( $p<0.039)$, так и
59.5 (SD: 5.1) years and mean RTL 0.65 (o.21). At follow-up mean RTL was 1.37 (0.40), as influenced by use of a different methodology based on a different control cell population. Baseline and follow-up clinical characteristics are shown in Table 1. In all 83 subjects had an MI (prevalent at baseline 33, and/or incident during follow-up: 56), and 67 subjects were treated with AHT drugs at baseline. The mean pulse pressure at baseline was $55.0 \pm 13.8 \mathrm{~mm} \mathrm{Hg}$.

In Fig. 1 are shown the z-score distribution at baseline (z-score ${ }_{\mathrm{BL}}$ ), at follow-up (z-score ${ }_{\mathrm{FU}}$ ), and as the calculated difference between measurements, reflecting telomere attrition ( $\Delta \mathrm{z}$-score).

When multiple regression analyses was applied, it was revealed that $\Delta \mathrm{z}$-score was independently associated with both total MI $(p<0.039)$ and usage of AHT drugs at baseline $(p<0.015)$, but not with pulse pressure at baseline, after full adjustment for chronological age, gender, and telomere length at baseline (Table 2). Change in relative telomere length in relation to trait (MI, AHT, pulse pressure) is shown in Table 3.

In this population-based case-control study it was shown that telomere attrition during 15 years of follow-up in middle-aged and elderly subjects was associated with two markers of cardiovascular ageing: total MI and usage of antihypertensive drugs. This was based on the statistical application

Таблица 1. Клинические характеристики 332 участников исследования ( 83 с ИМ и 249 без ИМ) при первичном и повторном через 15.7 года (SD: о.8) обследовании. Исследование Malmö Diet and Cancer

Table 1. Clinical characteristics of 332 study participants (83 MI-cases, and 249 non-MI controls), at baseline and after 15.7 years (SD: 0.8) of follow-up. The Malmö Diet and Cancer Study

\begin{tabular}{|c|c|}
\hline Показатель / Variable & Среднее значение / Mean \\
\hline \multicolumn{2}{|c|}{ Первичное обследование 1991-1994 г2. / Baseline 1991-1994 } \\
\hline Возраст (годы) / Age (years) & $59.5(\mathrm{SD} 5.1)$ \\
\hline $\operatorname{ИM}(n) / \operatorname{MI}(n)$ & 83 \\
\hline Прием АГП (\%) / AHT drug use (\%) & 67 \\
\hline Пульсовое давление (мм рт. ст.) / Pulse pressure (mm Hg) & $55.0(13.8)$ \\
\hline $\begin{array}{l}\text { Длина теломер / Telomere length } \\
\text { Среднее (SD) / Mean (SD) }\end{array}$ & $0.655(0.207)$ \\
\hline $\begin{array}{l}\text { z-оценка / Z-score } \\
\text { Среднее; SD (диапазон) / Mean; SD (range) }\end{array}$ & $\begin{array}{l}0.00(1.00) \\
(-2.99 ; 2.55)\end{array}$ \\
\hline \multicolumn{2}{|c|}{ Повторное обследование 2007-2009 г2. / Follow-up 2007-2009 } \\
\hline $\begin{array}{l}\text { Длина теломер / Telomere length } \\
\text { Среднее (SD) / Mean (SD) }\end{array}$ & $1.37(0.38)$ \\
\hline $\begin{array}{l}\text { z-оценка / Z-score } \\
\text { Среднее; SD (диапазон) / Mean; SD (range) }\end{array}$ & $\begin{array}{l}0.00(1.00) \\
(-3.28 ; 3.38)\end{array}$ \\
\hline \multicolumn{2}{|c|}{ Разница $(\Delta)$ / Difference $(\Delta)$} \\
\hline$\Delta \mathrm{z}$-оценка / $\Delta \mathrm{z}$-score & $0.00(1.23)$ \\
\hline$\Delta \mathrm{z}$-оценка (годы) / $\Delta \mathrm{z}$-score (year) & $0.015(0.785)$ \\
\hline
\end{tabular}


A

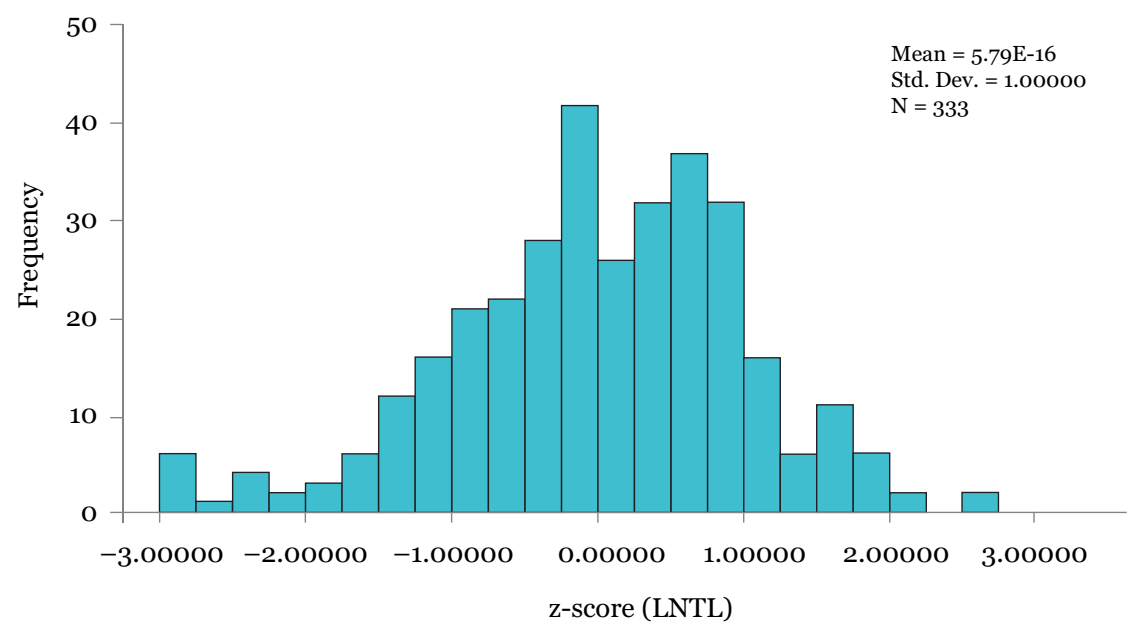

B

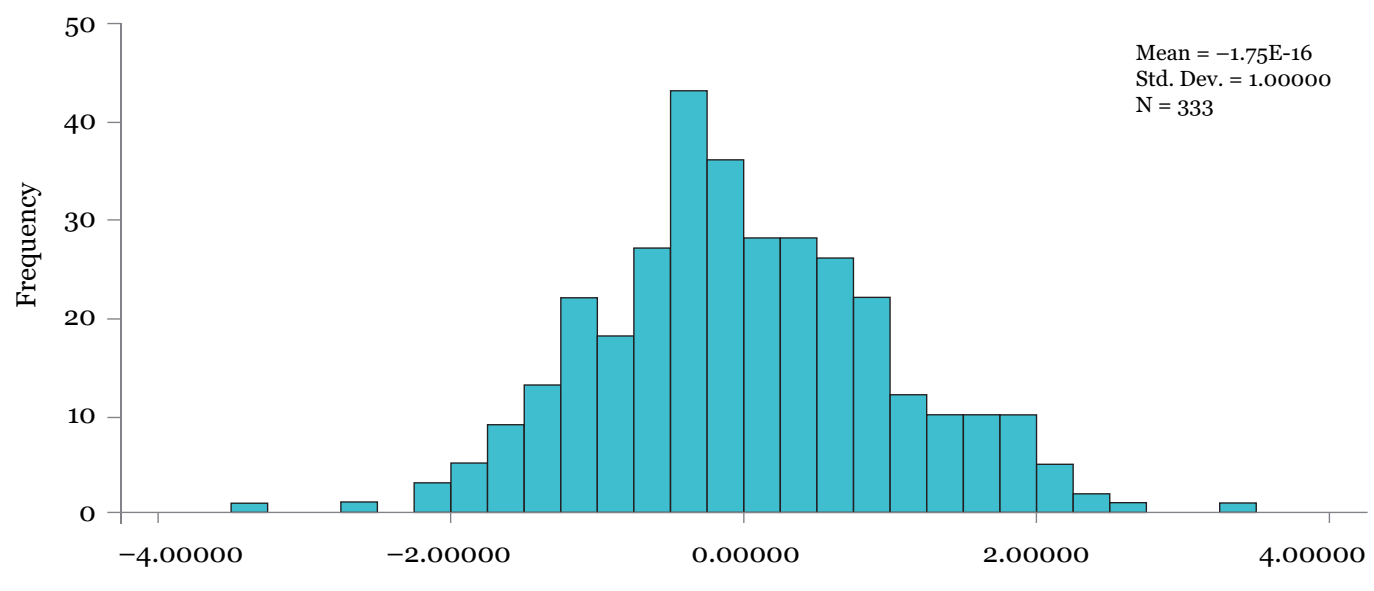

z-score (LN_TL_AUS)

$\mathrm{C}$

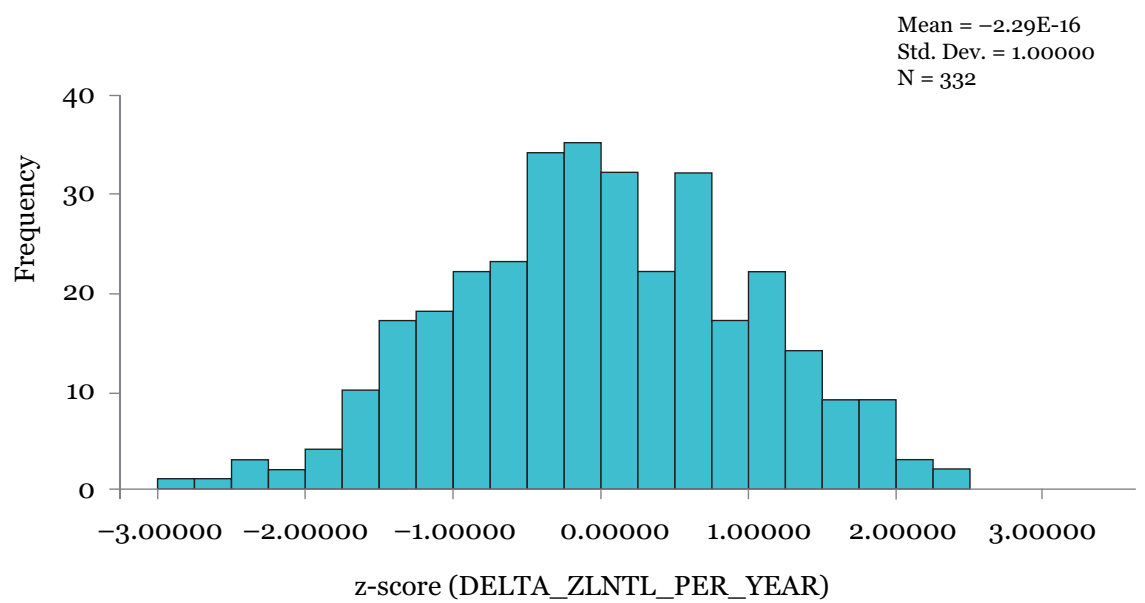

Рис. 1. Z-оценка при первичном (А) и повторном (В) обследовании и рассчитанная разница между ними (C) Fig. 1. The distribution of z-scores at baseline (A), follow-up (B), and for calculated difference between baseline and follow-up (C) 
Таблица 2. Множественный регрессионный анализ с $\Delta \mathrm{z}$-оценкой длины теломер (разница между z-оценкой при первичном и повторном обследованиях) в качестве зависимой переменной и приемом АГП или всеми случаями ИМ в качестве независимых переменных с учетом возраста, пола и исходной длины теломер (z-оценка)

Table 2. Multiple regression analyses with $\Delta$ z-score for telomere length (follow-up z-score minus baseline z-score) as dependent variable, and antihypertensive (AHT) drug use or total MI as independent variables, adjusted for age, gender and baseline telomere length $\left(\mathrm{z}\right.$-score $\left.{ }_{\mathrm{BL}}\right)$

\begin{tabular}{|c|c|c|c|c|}
\hline Показатель / Indicator & Бета / Beta & $\begin{array}{l}\text { Стандартная ошибка / } \\
\text { Std. error }\end{array}$ & $t$ & $p$ \\
\hline \multicolumn{5}{|c|}{$\begin{array}{c}\text { Прием АГП при первичном обследовании как независимая переменная } \\
\text { For AHT drug use at baseline (BL) as independent variable }\end{array}$} \\
\hline Константа / Constant & -1.15 & 0.51 & -2.24 & 0.026 \\
\hline Пол / Gender & -0.008 & 0.094 & -0.082 & 0.935 \\
\hline Возраст при первичном обследовании / Age at BL & 0.19 & 0.008 & 2.210 & 0.028 \\
\hline z-оценка при первичном обследовании / z-score BL & 0.623 & 0.043 & 14.40 & 0.001 \\
\hline Прием АГП / АHТ drug use & 0.264 & 0.107 & 2.45 & 0.015 \\
\hline \multicolumn{5}{|c|}{$\begin{array}{l}\text { Все случаи ИМ, произошедшие к первичному обследованию и в течение срока между обследованиями, } \\
\text { как независимая переменная / For total MI at baseline (BL) and during follow-up as independent variable }\end{array}$} \\
\hline Константа / Constant & -1.25 & 0.52 & -2.43 & 0.016 \\
\hline Пол / Gender & -0.17 & 0.094 & -0.186 & 0.853 \\
\hline Возраст при первичном обследовании / Age at BL & 0.021 & 0.008 & 2.458 & 0.014 \\
\hline z-оценка при первичном обследовании / z-score BL & 0.620 & 0.043 & 14.28 & 0.001 \\
\hline По всем случаям ИМ / Total MI & 0.206 & 0.099 & 2.07 & 0.039 \\
\hline
\end{tabular}

с приемом АГП к началу исследования $(p<0.015)$, но не с пульсовым давлением исходно. Влияние оказывали также такие факторы, как возраст, пол и исходная длина теломер (табл. 2). Изменение ОДТ в зависимости от фактора (ИМ, прием АГП, пульсовое давление) представлено в табл. 3 .

В данном исследовании показано, что укорочение теломер за 15 лет у лиц среднего и пожилого возраста связано с двумя маркерами возрастных изменений сердечно-сосудистой системы: ИМ и приемом АГП. Данный вывод основан на Z-оценке сравнений длины теломер между первичным и повторным обследованиями. Особое значение имели не только возраст и пол, но и исходная длина теломер, поскольку другие популяционные исследования показали важность этой переменной в определении скорости истощения теломер [16-18, 28]. of z-score comparisons between the distributions of telomere length at baseline at follow-up. Of special importance was to adjust not only for chronological age and gender but also for telomere length at baseline, as this has been shown to be of significant importance in determining the telomere attrition rate in other population-based studies [16-18, 28].

The use of total MI events as a marker of cardiovascular ageing [29-31] might be questioned in general terms, but as our subjects were all middleaged at baseline our prevalent MI-cases at baseline, in addition to incident MI-cases during follow-up, represent early manifestations of coronary heart disease in relation to the substantially higher mean age of MI-cases in the general population. We therefore believe that total MI in our cohort is a reliable marker of early cardiovascular ageing, one manifes-

Таблица 3. Изменение относительной длины теломер (ОДТ) ${ }^{1}$ по отношению к определенному фактору

Table 3. Change in relative telomere length (RTL) ${ }^{1}$ in relation to trait

\begin{tabular}{lll}
\hline Фактор / Тrait & Beta & $p$ \\
\hline Случаи инфаркта ${ }^{2}$ / Total MI ${ }^{2}$ & 0.206 & 0.039 \\
Прием АГП³ / АНТ drug use at baseline & 0.015 \\
Исходное пульсовое давление / Pulse pressure at baseline & 0.264 & 0.199 \\
\hline
\end{tabular}

${ }^{1} \Delta \mathrm{z}$-оценка/срок между обследованиями (лет) / $\Delta \mathrm{z}$-score/follow-up time in years.

${ }^{2}$ Произошедший до первичного обследования или после него (до 31 декабря 2006 г.) / Prevalent at baseline or incident during follow up (until Dec 31st 2006).

${ }^{3}$ Согласно анкете или личному дневнику наблюдений / According to questionnaire or diary book. 
Рассмотрение всех случаев ИМ в качестве маркера возрастных изменений сердечнососудистой системы [29-31] может быть поставлено под сомнение. Вместе с тем все участники в начале исследования были людьми среднего возраста - таким образом, случаи ИМ как до первичного обследования, так и после него представляют собой ранние проявления ИБС, поскольку средний возраст развития ИМ в популяции в целом существенно выше. По этой причине мы считаем, что ИМ в нашем исследовании является надежным маркером ранних возрастных изменений сердечно-сосудистой системы, одно из проявлений которого - ранняя манифестация ИБС.

Кроме того, прием АГП и пульсовое давление при первичном обследовании использовались в качестве потенциальных маркеров раннего артериального или раннего сосудистого старения (РСC), относимых к синдрому РСС [32]. Прием АГП у пациентов среднего возраста в начале 1990-х годов может быть расценен как признак гипертонии, что само по себе является маркером РСС. Рост пульсового давления отражает влияние повышенной артериальной жесткости (увеличенная скорость пульсовой волны (СПВ)), хотя и измеряется с меньшей точностью. К сожалению, нам не хватало данных о жесткости артерий и СПВ на первом этапе исследования. Повышение пульсового давления действительно было связано с укорочением теломер ( $\Delta \mathrm{z}$-оценка) после корректировки по возрасту и полу, но после корректировки по исходной длине теломер эта корреляция оказалась не значимой.

Ограничение нашего исследования состояло в том, что методы определения длины теломер при первичном и повторном обследовании отличались друг от друга. Вместе с тем при z-оценке мы применяли независимое распределение для данных двух этапов измерений. Это, по нашему мнению, является надежным способом преодолеть различия не только в применяемых методах, но и решить проблему использования несколько различных клеточных субпопуляций при двух измерениях, проведенных с 15-летним промежутком. Предыдущие исследования показали, что на длину теломер влияют также характеристики различных субпопуляций лейкоцитов [33], например, зафиксированы различия в силе связи между длиной теломер и возрастом в многоядерных лейкоцитах по сравнению с мононуклеарными лимфоцитами. tation being early coronary heart disease manifestations (MI).

In addition, we used both AHT drug usage and pulse pressure at baseline as potential markers of early arterial or early vascular ageing (EVA), what has also been referred to as the EVA syndrome [32]. A medical history of AHT drug usage in middle-age during the early 1990's could be taken as an indication of more or less longstanding hypertension in mid-life, in itself a marker of EVA. Increased pulse pressure is supposed to reflect the influence of increased arterial stiffness (increased pulse wave velocity, PWV), however measured with less precision. Regretfully we lacked data on arterial stiffness and PWV at the baseline investigation. Increased pulse pressure was indeed associated with telomere attrition ( $\Delta \mathrm{z}$-score) after adjustment for age and gender, but when also adjustment for telomere length at baseline was introduced to the model, this association turned non-significant.

A limitation of our study was that we were dependent on two somewhat differing methodologies to determine telomere length at baseline and at follow-up. However, by use of the z-score methodology we have used the independent distribution at the two measurements. This, we believe, is an accurate way to handle differences not only in the methodologies applied but also the potential problem of using slightly different cellular subpopulations at the two time-separated measurements. Previous studies have shown that telomere length is also influenced by characteristics of various subpopulations of white blood cells [33], e.g. recorded differences in the strength of the association between telomere length and chronological age in poly-nuclear leukocytes versus mononuclear lymphocytes.

Another limitation is that we could only include survivors during 15 years of follow-up and with no intermediate determination of telomere length. Therefore, subjects with more serious coronary heart disease (leading to fatal MI) or more severe hypertension could have been lost to follow-up. Finally, we did not include data on baseline cardiovascular risk factors, early atherosclerosis, inflammation, lifestyle variables or social factors for adjustments, even if such factors could be associated with telomere length [34-38]. Methods for determination of telomere length are constantly debated [39, 40], but as it has been shown that telomere length may predict mortality [41] there is still reason to believe that telomere length [42], as well as telomere changes [43], could represent aspects of cardiovascular pathophysiology of great biological importance. 
Еще одним ограничением нашего исследования было включение в него только тех, кто не умер в течение 15-летнего периода между обследованиями, а также отсутствие промежуточного определения длины теломер. По этой причине не выжившие пациенты с тяжелой формой ИБС или гипертонии не смогли участвовать в повторном обследовании. Наконец, в ходе анализа мы не использовали данные об исходных сердечнососудистых факторах риска, раннем атеросклерозе, воспалительных процессах, образе жизни или социальных факторах, хотя все они могут быть связаны с длиной теломер [34-38]. Методы определения длины теломер постоянно обсуждаются [39, 40], но поскольку известно, что длина теломер может быть предиктором смертности [41], все еще есть основания полагать, что длина теломер [42] и их истощение [43] представляют крайне важные биологические аспекты сердечно-сосудистой патофизиологии.

\section{ЗАКЛЮЧЕHИЕ}

В группе с ИМ и контрольной группе была выявлена связь между истощением теломер за период 15 лет между обследованиями и такими маркерами ранних возрастных изменений сердечно-сосудистой системы, как ИМ и прием АГП, являющимися признаками длительной гипертонии в среднем возрасте. Это способствует пониманию того, что сердечно-сосудистый риск в аспекте биологии теломер $[44,45]$ следует изучать с помощью повторных измерений длины теломер [46-49], не полагаясь лишь на перекрестные обследования или на единожды проведенные измерения. Еще много аспектов биологии теломер и их связи с сосудистой патологией требует дальнейшнго изучения [50].

\section{СПИСОК ЛИТЕРАТУРЫ}

1. Wong J.M., Collins K. Telomere maintenance and disease // Lancet. 2003. Vol. 362. P. 983-988.

2. Codd V., Mangino M., van der Harst P. et al. Common variants near TERC are associated with mean telomere length // Nat. Genet. 2010. Vol. 42. P. 197-199.

3. Ornish D., Lin J., Daubenmier J., Weidner G. et al. Increased telomerase activity and comprehensive lifestyle changes: a pilot study // Lancet Oncol. 2008. Vol. 9. P. 1048-1057. Erratum in: Lancet Oncol. 2008. Vol. 9. P. 1124.

4. Demissie S., Levy D., Benjamin E.J. et al. Insulin resistance, oxidative stress, hypertension, and leukocyte telomere length in men from the Framingham Heart Study // Aging Cell. 2006. Vol. 5. P. 325-330.

5. Jeanclos E., Schork N.J., Kyvik K.O. et al. Telomere length inversely correlates with pulse pressure and

\section{CONCLUSION}

In a population-based cohort of MI-cases and controls an association was shown between telomere attrition during 15 years of follow-up on the one hand with two markers of early cardiovascular ageing on the other hand, namely total MI and usage of AHT drugs, as an indication of longstanding hypertension in mid-life. This contributes to the conception that cardiovascular risk in relation to telomere biology $[44,45]$ should preferably by studied by use of repeated measurements of telomere length [46-49] and not rely on cross-sectional observations only or on single-measurements for prediction of risk. Still many aspects of telomere biology in relation to vascular disease remain to be investigated [50].

Conflict of interest. The authors declare no conflict of interest.

Acknowledgements. This study was supported by the following grants from the Research Council of Sweden (VR 521-2007-3533, and 5212010-2917) to PMN.

Funding this study was funded the Research Council and the Heart-Lung Foundation of Sweden.

Конфликт интересов. Авторы заявляют об отсутствии конфликта интересов.

Благодарности. Данное исследование выполнено при поддержке Исследовательского совета Швеции (гранты VR 521-2007-3533 и 5212010-2917).

Финансирование исследования осуществлено шведскими Исследовательским советом и Фондом «Сердце-легкие».

\section{REFERENCES}

1. Wong J.M., Collins K. (2003). Telomere maintenance and disease. Lancet, 362, 983-988.

2. Codd V., Mangino M., van der Harst P. et al. (2010). Common variants near TERC are associated with mean telomere length. Nat. Genet., 42, 197-199.

3. Ornish D., Lin J., Daubenmier J. et al. (2008). Increased telomerase activity and comprehensive lifestyle changes: a pilot study. Lancet Oncol., 9, 10481057. Erratum in: Lancet Oncol. (2008), 9, 1124.

4. Demissie S., Levy D., Benjamin E.J. et al. (2006). Insulin resistance, oxidative stress, hypertension, and leukocyte telomere length in men from the Framingham Heart Study. Aging Cell, 5, 325-330.

5. Jeanclos E., Schork N.J., Kyvik K.O. et al. (2000). Telomere length inversely correlates with pulse pressure and is highly familial. Hypertension, 36, 195-200. 
is highly familial // Hypertension. 2000. Vol. 36. P. 195-200.

6. Sampson M.J., Winterbone M.S., Hughes J.C., Dozio N., Hughes D.A. Monocyte telomere shortening and oxidative DNA damage in type 2 diabetes // Diabetes Care. 2006. Vol. 29. P. 283-289.

7. Olivieri F., Lorenzi M., Antonicelli R. et al. Leukocyte telomere shortening in elderly Type 2 DM patients with previous myocardial infarction // Atherosclerosis. 2009. Vol. 206. P. 588-593.

8. Gardner J.P., Li S., Srinivasan S.R., Chen W. et al. Rise in insulin resistance is associated with escalated telomere attrition // Circulation. 2005. Vol. 111. P. 21712177.

9. Brouilette S., Singh R.K., Thompson J.R., Goodall A.H., Samani N.J. White cell telomere length and risk of premature myocardial infarction // Arterioscler. Thromb. Vasc. Biol. 2003. Vol. 23. P. 842-846.

10. Fitzpatrick A.L., Kronmal R.A., Gardner J.P. et al. Leukocyte telomere length and cardiovascular disease in the cardiovascular health study // Am. J. Epidemiol. 2007. Vol. 165. P. 14-21.

11. Zee R.Y., Michaud S.E., Germer S., Ridker P.M. Association of shorter mean telomere length with risk of incident myocardial infarction: a prospective, nested case-control approach // Clin. Chim. Acta. 2009. Vol. 403. P. 139-141.

12. Zee R.Y., Ridker P.M., Chasman D.I. Genetic variants in eleven telomere-associated genes and the risk of incident cardio/cerebrovascular disease: The Women's Genome Health Study // Clin. Chim. Acta. 2011. Vol. 412. P. 199-202.

13. Atturu G., Brouilette S., Samani N.J. et al. Short leukocyte telomere length is associated with abdominal aortic aneurysm (AAA) // Eur. J. Vasc. Endovasc. Surg. 2010. Vol. 39. P. 559-564.

14. Valdes A.M., Andrew T., Gardner J.P. et al. Obesity, cigarette smoking, and telomere length in women // Lancet. 2005. Vol. 366. P. 662-664.

15. De Meyer T., Rietzschel E.R., De Buyzere M.L., Van Crieklinge W., Bekaert S. Studying telomeres in a longitudinal population based study // Front. Biosci. 2008. Vol. 13. P. 2960-2970.

16. Ehrlenbach S., Willeit P., Kiechl S. et al. Influences on the reduction of relative telomere length over 10 years in the population-based Bruneck Study: introduction of a well-controlled high-throughput assay // Int. J. Epidemiol. 2009. Vol. 38. P. 1725-1734.

17. Aviv A., Chen W., Gardner J.P. et al. Leukocyte telomere dynamics: longitudinal findings among young adults in the Bogalusa Heart Study // Am. J. Epidemiol. 2009. Vol. 169. P. 323-329.

18. Farzaneh-Far R., Lin J., Epel E., Lapham K., Blackburn E., Whooley M.A. Telomere length trajectory and its determinants in persons with coronary artery disease: longitudinal findings from the heart and soul study // PLoS One. 2010. Vol. 5:e8612.

19. Brouilette S.W., Moore S.J., MacMahon A.D. et al. Telomere length, risk of coronary heart disease, and statin treatment in the West of Scotland Coronary Protection Study: a nested case-control study // Lancet. 2007. Vol. 369. P. 107-114.

20. Hedblad B., Nilsson P., Janzon L., Berglund G. Relation between insulin resistance and carotid intimamedia thickness and stenosis in non-diabetic subjects.
6. Sampson M.J., Winterbone M.S., Hughes J.C., Dozio N., Hughes D.A. (2006). Monocyte telomere shortening and oxidative DNA damage in type 2 diabetes. Diabetes Care, 29, 283-289.

7. Olivieri F., Lorenzi M., Antonicelli R. et al. (2009). Leukocyte telomere shortening in elderly Type 2 DM patients with previous myocardial infarction. Atherosclerosis, 206, 588-593.

8. Gardner J.P., Li S., Srinivasan S.R. et al. (2005). Rise in insulin resistance is associated with escalated telomere attrition. Circulation, 111, 2171-2177.

9. Brouilette S., Singh R.K., Thompson J.R., Goodall A.H., Samani N.J. (2003). White cell telomere length and risk of premature myocardial infarction. Arterioscler. Thromb. Vasc. Biol., 23, 842-846.

10. Fitzpatrick A.L., Kronmal R.A., Gardner J.P. et al. (2007). Leukocyte telomere length and cardiovascular disease in the cardiovascular health study. Am. J. Epidemiol., 165, 14-21.

11. Zee R.Y., Michaud S.E., Germer S., Ridker P.M. (2009). Association of shorter mean telomere length with risk of incident myocardial infarction: a prospective, nested case-control approach. Clin. Chim. Acta, 403, 139-141.

12. Zee R.Y., Ridker P.M., Chasman D.I. (2011). Genetic variants in eleven telomere-associated genes and the risk of incident cardio/cerebrovascular disease: The Women's Genome Health Study. Clin. Chim. Acta, 412, 199-202.

13. Atturu G., Brouilette S., Samani N.J. et al. (2010). Short leukocyte telomere length is associated with abdominal aortic aneurysm (AAA). Eur. J. Vasc. Endovasc. Surg., $39,559-564$.

14. Valdes A.M., Andrew T., Gardner J.P. et al. (2005). Obesity, cigarette smoking, and telomere length in women. Lancet, 366, 662-664.

15. De Meyer T., Rietzschel E.R., De Buyzere M.L., Van Crieklinge W., Bekaert S. (2008). Studying telomeres in a longitudinal population based study. Front. Biosci., 13, 2960-2970.

16. Ehrlenbach S., Willeit P., Kiechl S. et al. (2009). Influences on the reduction of relative telomere length over 10 years in the population-based Bruneck Study: introduction of a well-controlled high-throughput assay. Int. J. Epidemiol., 38, 1725-1734.

17. Aviv A., Chen W., Gardner J.P. et al. (2009). Leukocyte telomere dynamics, longitudinal findings among young adults in the Bogalusa Heart Study. Am. J. Epidemiol., 169, 323-329.

18. Farzaneh-Far R., Lin J., Epel E. et al. (2010). Telomere length trajectory and its determinants in persons with coronary artery disease: longitudinal findings from the heart and soul study. PLoS One, 5:e8612.

19. Brouilette S.W., Moore S.J., MacMahon A.D. et al. (2007). Telomere length, risk of coronary heart disease, and statin treatment in the West of Scotland Coronary Protection Study: a nested case-control study. Lancet, $369,107-114$.

20. Hedblad B., Nilsson P., Janzon L., Berglund G. (2000). Relation between insulin resistance and carotid intima-media thickness and stenosis in nondiabetic subjects. Results from a cross-sectional study in Malmö, Sweden. Diabet Med., 17, 299307. 
Results from a cross-sectional study in Malmö, Sweden // Diabet. Med. 2000. Vol. 17. P. 299-307.

21. Manjer J., Carlsson S., Elmståhl S. et al. The Malmö Diet and Cancer Study: representativity, cancer incidence and mortality in participants and non-participants // Eur. J. Cancer. Prev. 2001. Vol. 10. P. 489-499.

22. Nordfjäll K., Eliasson M., Stegmayr B. et al. Telomere length is associated to obesity parameters but with a gender difference // Obesity. 2008. Vol. 16. P. 26822689.

23. Rosvall M., Janzon L., Berglund G. et al. Incident coronary events and case fatality in relation to common carotid intima-media thickness // J. Intern. Med. 2005. Vol. 257. P. 430-437.

24. The National Board of Health and Welfare. Evaluation of Quality of Diagnosis of Acute Myocardial Infarction, Inpatient Register 1997 and 1995. Stockholm, Sweden: National Board of Health and Welfare, 2000.

25. Nordfjall K., Osterman P., Melander O., Nilsson P., Roos G. hTERT (-1327)T/C polymorphism is not associated with age-related telomere attrition in peripheral blood // Biochem. Biophys. Res. Commun. 2007. Vol. 358. P. 215-218.

26. Cawthon R.M. Telomere measurement by quantitative PCR // Nucleic Acids Res. 2002. Vol. 30. P. 47.

27. Printhall R.C. Basic Statistical Analysis. Seventh Edition. Pearson Education Group, US, 2003.

28. Nordfjäll K., Svenson U., Norrback K.F. et al. The individual blood cell telomere attrition rate is telomere length dependent // PLoS Genet. 2009. Vol. 5 . P. 1000375 .

29. Samani N.J., van der Harst P. Biological ageing and cardiovascular disease // Heart. 2008. Vol. 94. P. 537539.

30. Minamino T., Komuro I. Vascular aging: insights from studies on cellular senescence, stem cell aging, and progeroid syndromes // Nat. Clin. Pract. Cardiovasc. Med. 2008. Vol. 5. P. 637-648.

31. Butt H.Z., Atturu G., London N.J., Sayers R.D., Bown M.J. Telomere length dynamics in vascular disease: a review // Eur. J. Vasc. Endovasc. Surg. 2010. Vol. 40. P. 17-26.

32. Nilsson P.M., Lurbe E., Laurent S. The early life origins of vascular ageing and cardiovascular risk: the EVA syndrome. (Review) // J. Hypertens. 2008. Vol. 26. P. 1049-1057.

33. Rufer N., Dragowska W., Thornbury G., Roosnek E., Lansdorp P.M. Telomere length dynamics in human lymphocyte subpopulations measured by flow cytometry // Nat. Biotechnol. 1998. Vol. 16. P. 743-747.

34. Bekaert S., De Meyer T., Rietzschel E.R. et al. Telomere length and cardiovascular risk factors in a middle-aged population free of overt cardiovascular disease // Aging Cell. 2007. Vol. 6. P. 639-647.

35. Nordfjäll K., Eliasson M., Stegmayr B. et al. Increased abdominal obesity, adverse psychosocial factors and shorter telomere length in persons reporting subjective early ageing; the MONICA Northern Sweden Study // Scand. J. Publ. Health. 2008. Vol. 36. P. 744-752.

36. Aviv A. The epidemiology of human telomeres: faults and promises // J. Gerontol. A Biol. Sci. Med. Sci. 2008. Vol. 63. P. 979-983.

37. Samani N.J., Boultby R., Butler R., Thompson J.R., Goodall A.H. Telomere shortening in atherosclerosis // Lancet. 2001. Vol. 358. P. 472-473.
21. Manjer J., Carlsson S., Elmståhl S. et al. (2001). The Malmö Diet and Cancer Study, representativity, cancer incidence and mortality in participants and nonparticipants. Eur. J. Cancer. Prev., 10, 489-499.

22. Nordfjäll K., Eliasson M., Stegmayr B. et al. (2008). Telomere length is associated to obesity parameters but with a gender difference. Obesity, 16, 26822689.

23. Rosvall M., Janzon L., Berglund G. et al. (2005). Incident coronary events and case fatality in relation to common carotid intima-media thickness. J. Intern. Med., 257, 430-437.

24. The National Board of Health and Welfare. Evaluation of Quality of Diagnosis of Acute Myocardial Infarction, Inpatient Register 1997 and 1995. (2000). Stockholm, Sweden, National Board of Health and Welfare.

25. Nordfjall K., Osterman P., Melander O., Nilsson P., Roos G. (2007). hTERT (-1327)T/C polymorphism is not associated with age-related telomere attrition in peripheral blood. Biochem. Biophys. Res. Commun., 358, 215-218.

26. Cawthon R.M. (2002). Telomere measurement by quantitative PCR. Nucleic Acids Res., 30:e47.

27. Printhall R.C. (2003). Basic Statistical Analysis. $17^{\text {th }}$ ed. Pearson Education Group, US.

28. Nordfjäll K., Svenson U., Norrback K.F. et al. (2009). The individual blood cell telomere attrition rate is telomere length dependent. PLoS Genet, 5:e1000375.

29. Samani N.J., van der Harst P. (2008). Biological ageing and cardiovascular disease. Heart, 94, 537-539.

30. Minamino T., Komuro I. (2008). Vascular aging: insights from studies on cellular senescence, stem cell aging, and progeroid syndromes. Nat. Clin. Pract. Cardiovasc. Med., 5, 637-648.

31. Butt H.Z., Atturu G., London N.J., Sayers R.D., Bown M.J. (2010). Telomere length dynamics in vascular disease: a review. Eur. J. Vasc. Endovasc. Surg., 40, 17-26.

32. Nilsson P.M., Lurbe E., Laurent S. (2008). The early life origins of vascular ageing and cardiovascular risk: the EVA syndrome. (Review). J. Hypertens., 26, 10491057.

33. Rufer N., Dragowska W., Thornbury G., Roosnek E., Lansdorp P.M. (1998). Telomere length dynamics in human lymphocyte subpopulations measured by flow cytometry. Nat. Biotechnol., 16, 743-747.

34. Bekaert S., De Meyer T., Rietzschel E.R. et al. (2007). Telomere length and cardiovascular risk factors in a middle-aged population free of overt cardiovascular disease. Aging Cell, 6, 639-647.

35. Nordfjäll K., Eliasson M., Stegmayr B. et al. (2008). Increased abdominal obesity, adverse psychosocial factors and shorter telomere length in persons reporting subjective early ageing; the MONICA Northern Sweden Study. Scand. J. Publ. Health, 36, 744-752.

36. Aviv A. (2008). The epidemiology of human telomeres: faults and promises. J. Gerontol. A Biol. Sci. Med. Sci., $63,979-983$.

37. Samani N.J., Boultby R., Butler R., Thompson J.R., Goodall A.H. (2001). Telomere shortening in atherosclerosis. Lancet, 358, 472-473.

38. O’Donnell C.J., Demissie S., Kimura M. et al. (2008). Leukocyte telomere length and carotid artery intimal 
38. O’Donnell C.J., Demissie S., Kimura M. et al. Leukocyte telomere length and carotid artery intimal medial thickness: The Framingham Heart Study // Arterioscler. Thromb. Vasc. Biol. 2008. Vol. 28. P. 1165-1171.

39. Aviv A., Valdes A.M., Spector D.M. Human telomere biology: pitfalls of moving from the laboratory to epidemiology // Int. J. Epidemiol. 2006. Vol. 35. P. 14241429.

40. Kimura M., Stone R.C., Hunt S.C. et al. Measurement of telomere length by the Southern blot analysis of terminal restriction fragment lengths // Nat. Protoc. 2010. Vol. 5. P. 1596-1607.

41. Cawthon R.M., Smith K.R., O'Brien E., Sivatchenko A., Kerber R.A. Association between telomere length in blood and mortality in people aged 60 years or older // Lancet. 2003. Vol. 361. P. 393-395.

42. De Meyer T., Rietzschel E.R., De Buyzere M.L., Van Criekinge W., Bekaert S. Telomere length and cardiovascular aging: The means to the ends? // Ageing Res. Rev. 2010 Nov 23. [Epub ahead of print].

43. Epel E.S., Merkin S.S., Cawthon R. et al. The rate of leukocyte telomere shortening predicts mortality from cardiovascular disease in elderly men // Aging (Albany NY). 2008. Vol. 1. P. 81-88.

44. Nilsson P.M., Tufvesson H., Leosdottir M., Melander O. Telomeres and cardiovascular disease risk: an update 2013 // Transl. Res. 2013. Vol. 162. P. 371-80.

45. Masi S., D’Aiuto F., Martin-Ruiz C. et al. NSHD scientific and data collection teams. Rate of telomere shortening and cardiovascular damage: a longitudinal study in the 1946 British Birth Cohort // Eur. Heart J. 2014 Dec 7. Vol. 35 (46). P. 3296-3303.

46. Rietzschel E.R., Bekaert S., De Meyer T. Telomeres and atherosclerosis: the attrition of an attractive hypothesis // J. Am. Coll. Cardiol. 2016 May 31. Vol. 67 (21). P. 2477-2479.

47. Weischer M., Bojesen S.E., Nordestgaard B.G. Telomere shortening unrelated to smoking, body weight, physical activity, and alcohol intake: 4,576 general population individuals with repeat measurements 10 years apart // PLoS Genet. 2014 Mar 13. Vol. 10 (3):e1004191.

48. Dalgård C., Benetos A., Verhulst S et al. Leukocyte telomere length dynamics in women and men: menopause vs age effects// Int. J. Epidemiol. 2015. Vol. 44 (5):1688-95.

49. Baragetti A., Palmen J., Garlaschelli K. et al. Telomere shortening over 6 years is associated with increased subclinical carotid vascular damage and worse cardiovascular prognosis in the general population // J. Intern Med. 2015 Apr. Vol. 277 (4). P. 478-487.

50. Ellehoj H., Bendix L., Osler M. Leucocyte telomere length and risk of cardiovascular disease in a cohort of 1,397 Danish men and women // Cardiology. 2016. Vol. 133 (3). P. 173-177.

\section{СВЕДЕНИЯ ОБ АВТОРАХ}

Нильсон Питер М. - MD, PhD, профессор (сердечнососудистые болезни). Отделение клинических наук, Исследовательская группа по сердечно-сосудистой генетике и сердечно-сосудистым болезням, Лундский университет, Университетская больница Сконе (Мальмё, Швеция). medial thickness: The Framingham Heart Study. Arterioscler. Thromb. Vasc. Biol., 28, 1165-1171.

39. Aviv A., Valdes A.M., Spector D.M. (2006). Human telomere biology, pitfalls of moving from the laboratory to epidemiology. Int. J. Epidemiol., 35, 1424-1429.

40. Kimura M., Stone R.C., Hunt S.C. et al. (2010). Measurement of telomere length by the Southern blot analysis of terminal restriction fragment lengths. Nat. Protoc., 5, 1596-1607.

41. Cawthon R.M., Smith K.R., O'Brien E., Sivatchenko A., Kerber R.A. (2003). Association between telomere length in blood and mortality in people aged 60 years or older. Lancet, 361, 393-395.

42. De Meyer T., Rietzschel E.R., De Buyzere M.L., Van Criekinge W., Bekaert S. (2010). Telomere length and cardiovascular aging: The means to the ends? Ageing Res. Rev. Nov 23. [Epub ahead of print].

43. Epel E.S., Merkin S.S., Cawthon R. et al. (2008). The rate of leukocyte telomere shortening predicts mortality from cardiovascular disease in elderly men. Aging (Albany NY), 1, 81-88.

44. Nilsson P.M., Tufvesson H., Leosdottir M., Melander O. (2013). Telomeres and cardiovascular disease risk: an update 2013. Transl. Res., 162, 371-380.

45. Masi S., D’Aiuto F., Martin-Ruiz C. et al. (2014). Rate of telomere shortening and cardiovascular damage: a longitudinal study in the 1946 British Birth Cohort. Eur. Heart J., 7, 35, 46, 3296-3303.

46. Rietzschel E.R., Bekaert S., De Meyer T. (2016). Telomeres and atherosclerosis: the attrition of an attractive hypothesis. J. Am. Coll. Cardiol., 67, 21, 2477-2479.

47. Weischer M., Bojesen S.E., Nordestgaard B.G. (2014). Telomere shortening unrelated to smoking, body weight, physical activity, and alcohol intake: 4,576 general population individuals with repeat measurements 10 years apart. PLoS Genet., 10, 3:e1004191.

48. Dalgård C., Benetos A., Verhulst S et al. (2015). Leukocyte telomere length dynamics in women and men: menopause vs age effects. Int. J. Epidemiol., 44, 5, 1688-1695.

49. Baragetti A., Palmen J., Garlaschelli K. et al. (2015). Telomere shortening over 6 years is associated with increased subclinical carotid vascular damage and worse cardiovascular prognosis in the general population. J. Intern. Med., 277, 4, 478-487.

50. Ellehoj H., Bendix L., Osler M. (2016). Leucocyte telomere length and risk of cardiovascular disease in a cohort of 1,397 danish men and women. Cardiology, 133, 3, 173-177.

\section{ABOUT THE AUTHORS}

Nilsson Peter M. - MD, PhD, Professor of Clinical Cardiovascular Research. Department of Clinical Sciences, Cardiovascular Genetics and Clinical Cardiovascular Research Group, Lund University, Skåne University Hospital (Malmö, Sweden).

Dahlman Disa - MD, PhD, Registrar Phisician. Department of Clinical Sciences, Cardiovascular Genetics and Clinical Cardiovascular Research Group (Malmö, Sweden).

Melander Olle - MD, PhD, Professor of Internal Medicine. Department of Clinical Sciences, Cardiovascular Genetics and Clinical Cardiovascular Research Group (Malmö, Sweden). 
Дальман Диса - MD, PhD, врач. Отделение клинических наук, Исследовательская группа по сердечнососудистой генетике и сердечно-сосудистым болезням, Лундский университет, Университетская больница Сконе (Мальмё, Швеция).

Меландер Олле - MD, PhD, профессор (внутренние болезни). Отделение клинических наук, Исследовательская группа по сердечно-сосудистой генетике и сердечно-сосудистым болезням, Лундский университет, Университетская больница Сконе (Мальмё, Швеция).

О бра зец ци ти рования : Нильсон П.М.,Дальман Д., Меландер О. Связь изменений относительной длины теломер в течение пятнадцати лет с маркерами возрастных изменений сердечно-сосудистой системы у лиц среднего возраста по результатам исследования питания и рака в Мальмё (Швеция) // Journal of Siberian Medical Sciences. 2019. № 1. C. 4-17.
Citation exa mple: Nilsson P.M., Dahlman D., Melander O. (2019). Change in relative telomere length over fifteen years is associated with markers of cardiovascular ageing in middle-aged subjects - the Malmö Diet and Cancer Study, Sweden. Journal of Siberian Medical Sciences, 1, 4-17. 